НАУКОВИЙ ВІСНИКК (1)

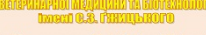

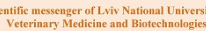

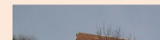

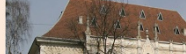
11) MIMMN

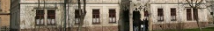

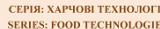
Том 23 № 96 2021
Науковий вісник Дьвівського національного університету ветеринарної медицини та біотехнодогій імені С.3. Гжицького. Серія: Харчові технології

\section{Scientific Messenger of Lviv National University} of Veterinary Medicine and Biotechnologies.

Series: Food Technologies doi: 10.32718/nvlvet-f9606 https://nvlvet.com.ua/index.php/food

UDC 664:637.12

\title{
Physical, chemical and organoleptic characteristics of plant milk, which is used in hotel and restaurant complexes
}

\author{
S. Merzlov, Yu. Shurchkova, A. Tsebro, O. Grebelnik, G. Kalinina, N. Rol \\ Bila Tserkva National Agrarian University, Bila Tserkva, Ukraine
}

Article info

Received 16.04.2021

Received in revised form 19.05.2021

Accepted 20.05.2021

Bila Tserkva National Agrarian University, Pl. Soborna $8 / 1$, Bila Tserkva, Kyiv region, 09117, Ukraine.

Tel. : +38-097-769-39-61 E-mail:anastasi-

ya.khomenko.ua@gmail.com

Merzlov, S., Shurchkova, Yu., Tsebro, A., Grebelnik, O., Kalinina, G., \& Rol, N. (2021). Physical, chemical and organoleptic characteristics of plant milk, which is used in hotel and restaurant complexes. Scientific Messenger of Lviv National University of Veterinary Medicine and Biotechnologies. Series: Food Technologies, 23(96), 28-32. doi: 10.32718/nvlvet-f9606

The article highlights the current state of the production of dairy and vegetable food products. The results of studies of organoleptic and physical, chemical indicators of the quality of various herbal drinks: coconut, almond and oat, are presented, as well as an analysis and comparison with cow's milk, which is used in hotel and restaurant complexes in Bela Tserkva. For assessing the quality according to the organoleptic characteristics of the beverages, the following were examined: appearance, color, smell, taste and consistency. It was found that according to these indicators, herbal drinks comply with the regulatory documentation for these products. When assessing the quality by physical and chemical indicators, the mass fraction of fat, dry matter, titratable and active acidity, and density were established. The titratable acidity of milk-like drinks was within the normal range and did not exceed $10^{\circ} \mathrm{T}$. The mass fraction of fat in coconut milk was $1.2 \%$, almond-rice milk-1.3\% and oat milk- $2.4 \%$. Mass fraction of coconut milk solids was $7.6 \%$, almond-rice $10.5 \%$ and oat milk $11.4 \%$. The density of all types of herbal drinks was in the range of $1005-1015 \mathrm{~kg} / \mathrm{m}^{3}$. The indicators of the quality of cow's milk, which is used in hotel and restaurant complexes, have been investigated in a comparative form. In terms of organoleptic indicators, the quality of cow's milk corresponds to the normative documentation. The fat mass fraction of cow's milk was $2.5 \%$, the mass fraction of solids was $12.5 \%$, the titratable acidity was at the level of $18^{\circ} \mathrm{T}$, the active acidity $\mathrm{pH}$ was 6.6 , and the density was $1028 \mathrm{~kg} / \mathrm{m}^{3}$. Analysis of various types of vegetable and cow's milk, which are used in hotel and restaurant complexes in the city of Bela Tserkva, in terms of physicochemical and organoleptic quality indicators, allows us to consider herbal drinks as substitutes for traditional products capable of providing the human body with essential nutritional factors.

Key words: functional food, vegetable drink, coconut milk, almond milk, oat milk, cow's milk, mass fraction of fat, mass fraction of dry substances, titratable acidity, active acidity.

\section{Фізико-хімічні та органолептичні показники рослинного молока, яке використовують у готельно-ресторанних комплексах}

\author{
С. В. Мерзлов, Ю. О. Шурчкова, А. Д. Цебро, О. П. Гребельник, Г. П. Калініна, Н. В. Роль
}

Білочерківський національний аграрний університет, м. Біла Церква, Украйна

\footnotetext{
У статті висвітлено сучасний стан виробництва молочно-рослинних харчових продуктів. Наведено результати досліджень органолептичних та фізико-хімічних показників якості різних рослинних напоӥв: кокосового, мигдального та вівсяного, а також проведено аналіз та порівняння з коров'ячим молоком, яке використовують у готельно-ресторанних комплексах м. Біла Церква. За проведення очінки якості за органолептичними показниками напоӥв досліджували: зовнішній вигляд, колір, запах, смак та консистенцію. Встановлено, щзо за цүими показниками рослинні напої відповідають нормативній документації на дані продукти. Під час проведення оцінки якості за фізико-хімічними показниками встановлювали масову частку жиру, сухих речовин, титровану та активну кислотність, густину. Титрована кислотність молокоподібних напоїв була в межах норми і не перевищує $10{ }^{\circ}$ Т. Масова частка жиру кокосового молока становила 1,2\%, мигдально-рисового - 1,3\% та вівсяного - 2,4\%. Масова частка сухих речовин кокосового молока становила - 7,6\%, мигдально-рисового 10,5\% та вівсяного - 11,4\%. Густина всіх видів рослинних напоїв була в
} 


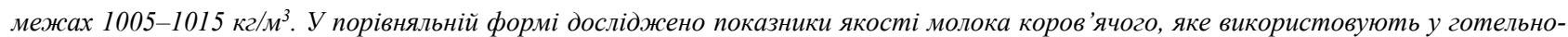
ресторанних комплексах. За органолептичними показниками якість молока коров'ячого відповідає нормативній документації. Масова частка жиру молока коров'ячого становила 2,5 \%, масова частка сухих речовин 12,5\%, титрована кислотність була на рівні $18^{\circ} \mathrm{T}$, активна кислотність рН-6,6, густина - 1028 кг/м ${ }^{3}$. Аналіз різних видів рослинного і коров ячого молока, які використовують у готельно-ресторанних комплексах м. Біла Церква за фізико-хімічними та органолептичними показниками якості дозволяє розглядати рослинні напої як замінники традиційних продуктів здатних забезпечувати організм людини есенціальними факторами живлення.

Ключові слова: функиіональні продукти харчування, рослинний напій, кокосове молоко, мигдальне молоко, вівсяне молоко, коров'яче молоко, масова частка жиру, масова частка сухих речовин, титрована кислотність, активна кислотність.

\section{Вступ}

3 кожним роком все більше уваги приділяють виробництву нетрадиційних та комбінованих молочнорослинних харчових продуктів, розробляють нові біотехнології за використання рослинної сировини та продуктів переробки сої, кокосу, мигдалю, насіння гарбуза, соняшнику, конопель. Впроваджують методи збагачення молока білком, у тому числі рослинним, створюють замінники коров'ячого молока тощо (Trufkati, 2006; Diakonova et al., 2016).

У сучасній харчовій промисловості з метою корекції раціонів харчування, підвищення зацікавленості споживачів, збільшення асортименту та конкурентоспроможності продуктів використовують функціональні компоненти: харчові волокна, вітаміни, мінеральні елементи, поліненасичені жирні кислоти, антиоксиданти, олігосахариди, які мають антиалергенні, антистресові, адаптогенні, тонізуючі, стимулюючі та радіопротекторні властивості. Це пов'язано зі збільшенням кількості людей, що страждають на алергію або мають надчутливість до білків тваринного походження, або у разі нездатності засвоювати молочний цукор - лактозу (Hramcova et al., 2012).

Однією з основних проблем харчової промисловості, у тому числі молочної, є забезпечення населення повноцінним білком. Сьогодні встановлено поступове заміщення у раціонах харчування білків тваринного походження рослинними. 3 метою забезпечення повноцінного харчування необхідно створювати та постійно розширювати асортимент продуктів, які за своїм складом повинні бути максимально наближені до складу натурального коров'ячого молока (Oupadissakoon et al., 2009; Diakonova et al., 2016).

Функціональні продукти та напої, які сприятливо впливають на здоров'я людини за їхнього регулярного вживання в оптимальних дозах, займають у раціоні харчування сучасної людини все більшу частку. Крім поживних речовин, вони містять функціональні інгредієнти, що допомагають адаптуватися до впливу навколишнього середовища, запобігти виникненню захворювань і попередити передчасне старіння. Широкий спектр таких речовин, представлено у продуктах рослинного походження (Trufkati, 2006).

Сьогодні особливу увагу споживачі приділяють молокоподібним напоям, що імітують смак, консистенцію та фізико-хімічні властивості молочних напоїв, проте їх виготовляють виключно з рослинної сировини (Onsaard et al., 2005). Їх можливо використовувати як замінник тваринного молока й виготовляти продукти на його основі, а також додавати до кулінарних страв. Такі напої є низькокалорійними, не міс- тять холестерину, лактози, крохмалю, гормонів та антибіотиків порівняно 3 молоком тваринного походження. За промислової технології виготовляють рослинні замінники молока із сої, рису, вівса, пшениці, різноманітних горіхів, а також 3 насіння маку, соняшника, гарбуза, льону, амаранту, конопель тощо (Samofalova \& Simonenkova, 2004; Oupadissakoon et al., 2010; Polishchuk, 2013).

Враховуючи зазначене, актуальним є дослідження спрямовані на проведення порівняльної оцінки складу замінників молока, які безпосередньо використовує споживач.

Метою статті є дослідження фізико-хімічних та органолептичних показників якості різних видів рослинного молока, яке використовують у готельноресторанних комплексах м. Біла Церква.

\section{Матеріал і методи досліджень}

Дослідження були проведені в умовах наукової лабораторії кафедри безпечності та якості харчових продуктів, сировини та технологічних процесів Білоцерківського національного аграрного університету.

Для проведення дослідження було відібрано проби відповідно до ДСТУ 4856:2007 трьох видів рослинних напоїв: кокосового "Alpro for professionals" з масовою часткою жиру 1,4 \%, мигдально-рисового “Ідеаль Немолоко" та вівсяного "Ідеаль Немолоко" з масовою часткою жиру, відповідно, 1,5 та 2,4 \%, а також молоко коров'яче “Селянське" $з$ масовою часткою жиру 2,5 \% відповідно до ДСТУ ISO 5538:2004, які використовують у готельно-ресторанних комплексах м. Білої Церкви.

Стандартний комплекс досліджень якості цих видів рослинних напоїв складався 3 двох методів: органолептична оцінка і оцінка фізико-хімічних показників.

Оцінка якості кокосового напою за органолептичними показниками була проведена відповідно до методики розробленої і запропонованої групою вчених S. Wattanapahu, T. Suwonsichon, W. Jirapakkul, S. Kasermsumran (Wattanapahu et al., 2012), вівсяного та мигдального молока відповідно до ДСТУ 7199:2009 (DSTU 7199:2009, 2011). Органолептичне оцінювання якості молока коров'ячого проводили відповідно до ДСТУ 2661:2010 (DSTU 2661:2010, 2010).

Під час проведення фізико-хімічних досліджень встановлювали показники, рекомендовані міжнародним стандартом на рідкі продукти з кокосових горіхів - Codex alimentarius CXS 240-2003 (Codex alimentarius international food standards, 2003). 
Визначення масової частки сухих речовин проводили за методикою, розробленою групою вчених (Phungamngoen et al., 2004). Метод грунтується на висушувані зразків у сушильній шафі за температури $102 \pm 2{ }^{\circ} \mathrm{C}$ протягом 2 годин до сталої маси.

Визначення титрованої кислотності рослинних напоїв та молока проводили титрометричним методом, активної кислотності $\mathrm{pH}$ - потенціометричним методом. Розбіжність між трьома паралельними вимірюваннями титрованої кислотності проб не перевищувала $1-2{ }^{\circ} \mathrm{T}$. За кінцевий результат вимірювань брали середнє арифметичне значення результатів обчислень. Масову частку жиру визначали кислотним методом Гербера відповідно до ДСТУ ISO 488:2007 (DSTU ISO 488:2007, 2009), визначення густини - аерометричним методом ДСТУ 6082:2009 (DSTU 6082:2009, 2009).

\section{Результати та їх обговорення}

Встановлено, що напій кокосовий “Alpro for professionals" за зовнішнім виглядом відповідав однорідній, непрозорій рідині, білого кольору, із приємним, слабо вираженим кокосовим запахом. Напій мав характерний солодкуватий специфічний смак та однорідну консистенцію.
Напій мигдально-рисовий “Ідеаль Немолоко” за зовнішнім виглядом це однорідна, непрозора рідина, кремового кольору, має приємний аромат мигдалю, на смак солодкуватий з горіховим присмаком, консистенція однорідна.

Дослідження показало, що вівсяний напій “Ідеаль Немолоко” є однорідною непрозорою рідиною, білого кольору з сірим відтінком. Запах був приємний, смак солодкуватий, відчувався присмак зерна вівса. Консистенція продукту була однорідна, без осаду.

Також досліджено показники якості молока коров'ячого “Селянське”. Зовнішній вигляд та консистенція продукту однорідна рідина без осаду, смак та запах чисті, з легким присмаком пастеризації. Колір білий, рівномірний за всією масою.

Отже, дослідні рослинні напої за деякими органолептичними показниками $є$ подібні до коров'ячого молока - це рідина солодкувата на смак. Колір напоїв $\epsilon$ ідентичний білий (“Alpro for professionals" та вівсяний напій “Ідеаль Немолоко”) або наближений кремовий (мигдально-рисовий напій “Ідеаль Немолоко”), Консистенція напоїв була ідентична натуральному молоку. За смаком та запахом напої відрізнялись від натурального молока, залежно від виду сировини, 3 якої виготовлено (мигдалю, кокосу, вівса).

\section{Таблиця 1}

Органолептичні показники рослинного та коров'ячого молока

\begin{tabular}{|c|c|c|c|c|}
\hline \multirow[b]{2}{*}{ Показник } & \multicolumn{4}{|c|}{ Характеристика } \\
\hline & $\begin{array}{l}\text { Кокосове молоко “Alpro } \\
\text { for professionals" }\end{array}$ & $\begin{array}{c}\text { Мигдально-рисове “Ідеаль } \\
\text { Немолоко” }\end{array}$ & $\begin{array}{c}\text { Вівсяне молоко "Ідеаль } \\
\text { Немолоко" }\end{array}$ & $\begin{array}{l}\text { Молоко коров'яче } \\
\text { "Селянське" }\end{array}$ \\
\hline $\begin{array}{l}\text { Зовнішній } \\
\text { вигляд }\end{array}$ & $\begin{array}{c}\text { Однорідна, непрозора } \\
\text { рідина }\end{array}$ & $\begin{array}{c}\text { Однорідна, непрозора } \\
\text { рідина }\end{array}$ & $\begin{array}{c}\text { Однорідна, непрозора } \\
\text { рідина }\end{array}$ & $\begin{array}{c}\text { Однорідна, непрозо- } \\
\text { ра рідина }\end{array}$ \\
\hline Колір & Білий & Кремовий & Білий з сірим відтінком & Білий \\
\hline Запах & $\begin{array}{c}\text { Приємний, слабко } \\
\text { виражений кокосовий }\end{array}$ & Приємний & Приємний & $\begin{array}{l}\text { Чисті, без сторонніх } \\
\text { присмаків та запахів, }\end{array}$ \\
\hline Смак & $\begin{array}{l}\text { Характерний, солодкий, } \\
\text { відчувається смак кокосу }\end{array}$ & $\begin{array}{c}\text { Солодкуватий, горіховий } \\
\text { присмак }\end{array}$ & $\begin{array}{c}\text { Солодкуватий, приєм- } \\
\text { ний присмак зерна вівса }\end{array}$ & $\begin{array}{c}3 \text { легким присмаком } \\
\text { пастеризації }\end{array}$ \\
\hline $\begin{array}{l}\text { Консис- } \\
\text { тенція }\end{array}$ & Однорідна & Однорідна & Однорідна & Однорідна \\
\hline
\end{tabular}

Під час дослідження якості напоїв та коров'ячого молока за фізико-хімічними показниками визначали: активну та титровану кислотність, масову частку жиру та сухих речовин, густину (табл. 2). Активна кислотність молока коров'ячого становила 6,6. Показники $\mathrm{pH}$ кокосового молока "Alpro for professionals" вірогідно не відрізнявся від молока коров’ячого. Підвищення активної кислотності було лише на 1,5\%. Активна кислотність мигдально-рисового та вівсяного молока була однаковою в межах $\mathrm{pH}$ 6,8. Показники вірогідно не відрізнялись від молока коров'ячого.

Встановлено, що титрована кислотність кокосового молока становила $10^{\circ} \mathrm{T}$, мигдально-рисового та вівсяного по $8^{\circ} \mathrm{T}$. Титрована кислотність кокосового молока була у $1,8(\mathrm{P} \leq 0,001)$ рази меншою порівняно iз молоком коров'ячим. Показники титрованої кислотності мигдально-росового та вівсяного молока були однаковими. Порівнюючи до молока коров'ячого даний показник був у 2,25 рази меншим $(\mathrm{P} \leq 0,001)$. Відхилень показників активної та титрованої кислотності від встановлених норм дослідних рослинних напоїв та коров'ячого молока не було виявлено.

Порівнюючи фізико-хімічні показники молока коров'ячого та рослинного, варто відмітити, що молокоподібні продукти дещо відрізняються від традиційних за масовою часткою жиру, вміст сухих речовин та густиною. Отже, масова частка жиру у кокосовому молоці є нижчою на 1,3 \%, у мигдально-рисовому - на 1,2 \% та у вівсяному - на 0,1 \%, порівняно з аналогічним показником у коров'ячому молоці.

Масова частка сухих речовин у кокосовому молоці становила 7,6 \%, у мигдально-рисовому та вівсяному, відповідно, 10,5 та 11,4%. Порівнюючи до молока коров'ячого масова частка сухих речовин у кокосовому молоці вірогідно була меншою. Різниця становила $4,9 \%$. 
Таблиця 2

Фізико-хімічні показники різних видів рослинного молока, $\mathrm{n}=10, \mathrm{M} \pm \mathrm{m}$

\begin{tabular}{lcccc}
\hline \multicolumn{1}{c}{ Показники } & $\begin{array}{c}\text { Кокосове молоко “Alpro } \\
\text { for professionals" }\end{array}$ & $\begin{array}{c}\text { Мигдально-рисове } \\
\text { “Ідеаль Немолоко” }\end{array}$ & $\begin{array}{c}\text { Вівсяне молоко } \\
\text { “Ідеаль Немолоко” }\end{array}$ & $\begin{array}{c}\text { Молоко коров'яче } \\
\text { “Селянське” }\end{array}$ \\
\hline Активна кислотність, $\mathrm{pH}$ & $6,7 \pm 0,05$ & $6,8 \pm 0,03$ & $6,8 \pm 0,02$ & $6,6 \pm 0,03$ \\
Титрована кислотність, ${ }^{\circ} \mathrm{T}$ & $10,0 \pm 0,57 * * *$ & $8,6 \pm 0,33^{* * *}$ & $8,6 \pm 0,33^{* * *}$ & $18,3 \pm 0,18$ \\
Масова частка жиру, \% & $1,2 \pm 0,09^{* *}$ & $1,3 \pm 0,08^{* *}$ & $2,4 \pm 0,13$ & $2,5 \pm 0,14$ \\
Масова частка сухих речовин, \% & $7,60 \pm 0,418^{* *}$ & $10,50 \pm 0,322^{*}$ & $11,46 \pm 0,318$ & $12,50 \pm 0,425$ \\
Густина, кг $/ \mathrm{m}^{3}$ & $1010,5 \pm 4,32^{*}$ & $1010 \pm 3,36^{*}$ & $1015,0 \pm 5,18$ & $1028,0 \pm 4,16$ \\
\hline
\end{tabular}

Примітка: * $\mathrm{P} \leq 0,05 ; * * \mathrm{P} \leq 0,01 ; * * * \mathrm{P} \leq 0,001$

Слід відмітити, що вівсяне молоко за вмістом сухих речовин вірогідно не відрізнялось від молока коров'ячого із масовою часткою жиру $2,5 \%$. Встановлено, що густина рослинного молока була в межах

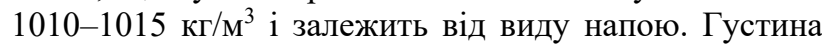
коров'ячого молока більша - 1028 кг/м ${ }^{3}$. Найнижчу густину мали кокосове і мигдально-рисове молоко, що може пояснюватись масовою часткою жиру в продуктах на рівні 1,2-1,3\%.

Отже, результати дослідження показали, що за фізико-хімічними та органолептичними показниками рослинне молоко подібне до коров'ячого. Проте, густина і масова частка жиру є меншою у кокосовому та мигдально-рисовому напоях. Порівнюючи вівсяне і коров'яче молоко суттєвої різниці за цими показниками відмічено не було.

Органолептичні показники (смак, запах) кокосового, мигдально-рисового та вівсяного молока були трохи специфічними відносно молока коров'ячого, проте дані ознаки урізноманітнюють асортимент напоїв за смаковими якостями.

\section{Висновки}

1. Досліджено фізико-хімічні та органолептичні показники якості різних видів рослинного молока: кокосове молоко “Alpro for professionals", мигдальнорисове "Ідеаль Немолоко", вівсяне молоко "Ідеаль Немолоко” у порівнянні із коров'ячим молоком, які використовують у готельно-ресторанних комплексах м. Біла Церква.

2. За органолептичними показниками дослідні рослинні напої подібні до коров'ячого молока - це рідина солодкувата на смак, від білого до кремового кольору, з характерним присмаком, залежно від виду сировини, з якої виготовлено (мигдалю, кокосу, вівса), однорідної консистенції.

3. Показник активної кислотності кокосового, мигдально-рисового та вівсяного напоїв наближений до нейтрального, в межах 6,7-6,8, молока коров'ячого $-6,6$.

4. Густина кокосового, мигдально-рисового та вівсяного напоїв, знаходилась у межах 10101015 кг $/ \mathrm{M}^{3}$, густина коров'ячого молока становить $1028 \mathrm{\kappa} / \mathrm{M}^{3}$.

5. Масова частка жиру у кокосовому молоці $\epsilon$ нижчою на 1,3\%, у мигдально-рисовому - на 1,2 \% та у вівсяному - на $0,1 \%$, порівняно з аналогічним показником у коров'ячому молоці.
6. Масова частка сухих речовин у кокосовому молоці становила 7,6\%, у мигдально-рисовому та вівсяному, відповідно, 10,5 та 11,4 \%, у коров'ячому молоці - $12,5 \%$.

\section{References}

Codex alimentarius international food standards. Standard for aqueous coconut prodacts. Coconut Milk and Coconut Cream. CXS 240-2003 [Amended in 2019] Adopted in 2003. p. 5.

Diakonova, A. K., \& Stepanova, V. S. (2016). Vyrobnytstvo roslynnoho zaminnyka moloka. Progressive technique and technologies of food production enterprises, catering business and trade, Kharkiv, KSUFTT, 2(24), 127-136. URL: https:/elib.hduht.edu.ua/bitstream/123456789/1177/1/ 1.10.pdf (in Ukrainian).

DSTU 2661:2010 (2010). Zahalni tekhnichni umovy [Chynnyi vid 2011-10-01]. Vyd. Ofits. Kyiv: Derzhspozhyvstandart Ukrainy (in Ukrainian).

DSTU 4856:2007 (2009). Produktsiia bezalkoholnoi promyslovosti. Pravyla pryimannia ta metody vidbyrannia prob [Chynnyi vid 2009-01-01]. Vyd. Ofits. Kyiv: Derzhspozhyvstandart Ukrainy (in Ukrainian).

DSTU 6082:2009 (2009). Moloko ta molochni produkty. Metody vyznachannia hustyny [Chynnyi vid 2009-0701] Vyd. ofits. Kyiv: Derzhspozhyvstandart Ukrainy (in Ukrainian).

DSTU 7199:2009 (2011). Produktsiia bezalkoholnoi promyslovosti. Metody vyznachannia orhanoleptychnykh pokaznykiv, obiemu produktsii ta hermetychnosti zakuporiuvannia [Chynnyi vid 201101-01]. Vyd. Ofits. Kyiv: Derzhspozhyvstandart Ukrainy (in Ukrainian).

DSTU ISO 488:2007 (2009). Moloko. Vyznachannia masovoi chastky zhyru. Zhyromiry Gerbera (ISO 488:1983, IDT) [Chynnyi vid 2009-01-01] Vyd. ofits. Kyiv: Derzhspozhyvstandart Ukrainy (in Ukrainian).

DSTU ISO 5538:2004 (2006). Moloko ta molochni produkty. Vidbyrannia prob. Kontrol za yakisnymy oznakamy (ISO 5538:1987, IDT) [Chynnyi vid 2006-0401]. Vyd. Ofits.,. Kyiv: Derzhspozhyvstandart Ukrainy (in Ukrainian).

Hramcova, A. G., Brykalov, A. V., \& Pilipenko, N. Y. (2012). Napitki iz syvorotki s rastitel'nymi komponentami. Molochnaya promyshlennost', 7, 6466 (in Russian).

Minevich, I. Je., \& Grigor'eva, A. L. (2008). Sposob prigotovleniya rastitel'nogo moloka iz semyan l'na: 
pat. Rossijskaya Federaciya, MPK A23C 11/10. № 2333656; zayavl. 26.02.07; opubl. 20.09.08. URL: https://findpatent.ru/patent/233/2333656.html (in Russian).

Onsaard, E., Vittayanont, M., Sringam, S., \& McClements, D. J. (2005). Properties and stability of oil-in-water emulsion stabilized by coconut skim milk protein. J. Agri Food Chem., 53(14), 5747-5753. doi: $10.1021 / \mathrm{jf050312r}$.

Oupadissakoon, C., Chamber, E., Kongpensook, V., Suwonsichon, S., Yenket, R., \& Retiveu, A. (2010). Sensory properties and consumer acceptance of sweet tamarind varieties grown in Thailand. J. Sci. Food Agric., 90(6), 1081-1088. doi: 10.1002/jsfa.3925.

Oupadissakoon, G., Chambers, D. H., \& Chambers, E. (2009). Comparison of the sensory properties of UHT milk from different countries. J. Sensory Studies, 24(3), 427-440. doi: 10.1111/j.1745-459X.2009.00219.x.

Phungamngoen, C., Chiewchan, N., \& Siriwattanayothin, S. (2004). Effect of some stabilizers on the quality of canned high fat coconut milk. KMUTT R\&D J., 27, 375-390. URL: https://www.researchgate.net/publication/284699866 Effect_of_some_stabilizers_on_the_quality_of_canned_hig h_fat_coconut_milk.
Polishchuk, H. Ye. (2013). Formuvannia skladnykh dyspersnykh system molochnoho morozyva $\mathrm{Z}$ naturalnymy komponentamy: dys. ... d-ra tekhn. nauk Kyiv: NUKhT (in Ukrainian).

Samofalova, L. A., \& Simonenkova, A. P. (2004). Issledovanie tekhnologicheskih svojstv emul'sij rastitel'nogo moloka kak syr'ya dlya proizvodstva morozhenogo i ocenka kachestva smesej. Pishchevaya promyshlennost', 6, 88-89 (in Russian).

Samofalova, L. A., Simonenkova, A. P., Golyshkin, L. V. (2003). Issledovanie dispersij rastitel'nogo moloka iz semyan kul'turnoj konopli. Izvestiya OrelGTU. Legkaya i pishchevaya promyshlennost', 3-4, 39-44 (in Russian).

Trufkati, L. V (2006). Rozrobka biotekhnolohii kombinovanykh molochno-roslynnykh produktiv: avtoref. dys. na zdobuttia nauk. st.. kand. tekhn. nauk: 03.00.20. Odesa (in Ukrainian).

Wattanapahu, S., Suwonsichon, T., Jirapakkul, W., \& Kasermsumran, S. (2012). Categorization of Coconut Milk Products by Their Sensory Characteristics. Kasetsart J. (Nat. Sci.), 46, 944-954. URL: https://citeseerx.ist.psu.edu/viewdoc/download?doi=1 $0.1 .1 .1067 .8112 \&$ rep $=$ rep1\&type $=$ pdf. 